\title{
Article
}

\section{Ezekiel, Daniel, and Christian Diet Culture}

\author{
Stacy Davis
}

check for

updates

Citation: Davis, Stacy. 2022. Ezekiel, Daniel, and Christian Diet Culture. Religions 13: 182. https://doi.org/ 10.3390/rel13020182

Academic Editor: Bradford

A. Anderson

Received: 25 January 2022

Accepted: 16 February 2022

Published: 18 February 2022

Publisher's Note: MDPI stays neutral with regard to jurisdictional claims in published maps and institutional affiliations.

Copyright: (c) 2022 by the author. Licensee MDPI, Basel, Switzerland. This article is an open access article distributed under the terms and conditions of the Creative Commons Attribution (CC BY) license (https:// creativecommons.org/licenses/by/ $4.0 /)$.
Department of Religious Studies and Theology, Saint Mary's College, Notre Dame, IN 46556, USA; sdavis@saintmarys.edu

\begin{abstract}
The books of Ezekiel and Daniel, specifically Ezek 4.9 and Daniel 1, 3, and 6, are now being used to market healthy eating and diet plans to Christians, especially evangelical Christians, in ways that are the opposite of how the texts appear in their historical and literary contexts. Such usage is a potentially problematic example of prophetic reception history and its contemporary significance because the language in these plans is the same language found in secular diet plans with biblical prooftexts added to them. The addition may actually make the plans even more problematic by linking weight and fitness to religion and spirituality.
\end{abstract}

Keywords: Ezekiel; Daniel; diet culture

\section{Introduction}

In the United States, the month of January has become synonymous with self-improvement plans that focus on the body. Dry January participants abstain from alcohol, and Veganuary encourages people to eat no animal products for the month. Underneath the stated goals of improving health (What We Do 2022; Dry January 2022), however, is a much larger and often problematic discourse about weight. According to the National Eating Disorders Association, diet culture's main issues are as follows:

[It] conflates size and health, pathologizing some body sizes; encourages following external rules about what, when, and how much to eat; suggests that people are more or less good/moral/worthy based on their body size; creates thin privilege, which makes thinness a gatekeeper for jobs/benefits/comfort/accommodation; suggests movement and punishment for, or the prevention of, being fat, rather than for other reasons such as fun, or personal goals; and views fat people as less valuable and more riskable. (Chastain 2022)

While the emphasis on dieting and weight control is not new, the use of Hebrew Bible texts to support this emphasis is new. A simple research plan to analyze Ezekiel bread (inspired by Ezek 4.9) led to the discovery of multiple Christian diet plans, including one based on the book of Daniel. Unlike in the Jewish canon, Daniel functions as a Christian prophetic text and therefore appears here. In context, Ezekiel and Daniel become justifications for diet culture in ways that the original authors did not intend. This is not surprising or even wrong. As Patricia Tull helpfully states, "When contexts change, interpretation is altered" (Tull 1999, p. 158). However, 2 Tim 3.16-17 also states that scripture should instruct the reader and help them to become better. It is here that the readings of Ezekiel and Daniel may fall short. Christian diet culture prooftexts the Bible in order to rationalize otherwise secular diet and exercise plans. This prooftexting may create even more harm because, if one fails at the plan, the failure becomes a spiritual and not just a physical one.

\section{Christian Diet Culture}

Christian diet culture focuses on diet and exercise as necessary tools for maintaining the body that God created, with varying emphases on the importance of a healthy lifestyle. The concept has been around since the 1950s (Kwan and Sheikh 2011, p. 205); however, it 
comes out of a transition from fasting as a form of penance to "the growing anxiety about weight control and health among Christians of the eighteenth and nineteenth centuries" (Griffith 1999, p. 218). Samantha Kwan and Christine Sheikh note the connections between Christian and secular diet culture: "Western body discourses make various assumptions about fat and fat bodies that construct the discursive milieu in which Christian elites generate their own uniquely Christ-centered understanding of the appropriate body" (Kwan and Sheikh 2011, pp. 207-8). Both traditions assume body change is about willpower and, especially, that fat is inevitably unhealthy (Kwan and Sheikh 2011, pp. 208-9, 213, 216). In a recent study of predominantly White churches in Texas, Mark D. Faries, Megan McClendon, and Eric J. Jones note that a majority of the survey participants thought of smoking, alcohol consumption, and drug use as more sinful than a poor diet and lack of exercise (Faries et al. 2020, pp. 522, 524-25). The authors write, "Interestingly, only half of the sample was definite that overeating destroyed the body, and less than half was definite that unhealthy eating and a physically inactive lifestyle destroyed the body. Yet, the scientific evidence points to these factors as two of the top three true causes of chronic disease death" (Faries et al. 2020, p. 529). They suggest that some people may be unaware of the statistics about chronic disease or may not connect food and exercise to spiritual identity (Faries et al. 2020, p. 530).

The survey participants, however, may be exceptions that prove the rule. A 2013 Christianity Today article notes the growing number of "faith-based wellness programs" and "faith-based diet and nutrition books" (Fields 2013, p. 39). More Christians are beginning to pay more attention to their diets. Christian actors such as Chris Pratt have participated in the Daniel fast, or "21 days of prayer and fasting" (Nittle 2019). Nadra Nittle observes that "the Bible, of course, was one of the earliest sources to divide foods into 'clean' and 'unclean' categories" (Nittle 2019). She warns, however, that "many of the other Bible-inspired diet plans have been criticized for their extreme caloric restrictions. In that way, they're not much different from more mainstream fasts and cleanses" (Nittle 2019). Samantha Kwan and Christine Sheikh divide the diets into two categories-Success with God (praying for strength to lose the weight) and Garden of Eden (picking the proper biblically based foods) (Kwan and Sheikh 2011, p. 207). ${ }^{1}$

The emphasis upon God's help and the "religious obligation" to be fit is the primary distinction between Christian diet programs and secular ones (Kwan and Sheikh 2011, p. 209). Practically, this may also include "a Bible verse on every page" and exercising to Christian music; consequently, Leslie Leyland Fields writes, "Such programs raise the question of whether the church health movement is just baptizing broader health-andfitness culture in Jesus-y marketing language" (Fields 2013, p. 42). Unfortunately, Fields then potentially stumbles into anti-Jewish territory by saying, "When we overemphasize the 'good' of good health, we may stumble into the mindset of the Jews in Jesus' day who equated disability and disease with sin" (Fields 2013, p. 43). ${ }^{2}$ Even with this trickiness, Fields has a point. Linking weight loss to God, who "'cannot fail'" (Kwan and Sheikh 2011, p. 210), and one's relationship to God sounds suspiciously like an offshoot of the prosperity gospel-in this case, one's reduced weight shows God's favor. These movements are almost exclusively Protestant. As R. Marie Griffith argues, "It is quite evident that the transformation of fasting into dieting is largely a Protestant story" (Griffith 1999, p. 218). This may be due, in part, to the emphasis on applying the Bible to all parts of life, as the uses of Ezekiel and Daniel suggest.

\section{Ezekiel and His Transformation into a Bread Salesman}

The makers of Ezekiel Bread base their recipe on Ezek 4.9a while ignoring the chapter's larger context of siege and trauma. The verse reads as follows: "And you, take wheat and barley, beans and lentils, millet and spelt; put them into one vessel, and make bread for yourself". The rest of the verse, however, says this: "During the number of days that you lie on your side, three hundred ninety days, you shall eat it" (Ezek 4.9b). God orders Ezekiel to physically embody Israel and Judah's punishment for their sins by lying on his left and then 
right side for over a year. God states, "You shall set your face toward the siege of Jerusalem, and with your arm bared you shall prophesy against it. See, I am putting cords on you so that you cannot turn from one side to the other until you have completed the days of your siege" (Ezek 4.7-8). The bread Ezekiel makes symbolizes death and destruction and contributes to his misery and not his health. To add injury to insult, Ezekiel may only eat twenty shekels of the bread per day with one-sixth of a hin of water, consumed "at fixed times" (Ezek 4.11). This is approximately ten ounces of bread and about six hundred milliliters of water (Ganzel 2014, p. 1043). As Tova Ganzel notes, "The amounts of food and water were barely enough to sustain the prophet. Ezekiel mixes a variety of grains, including those not normally used to make bread, to demonstrate that there is insufficient grain to make an entire loaf of bread" (Ganzel 2014, p. 1043). Furthermore, the bread must be baked over human excrement as a sign of uncleanness. Ezekiel pleads for mercy, and God decrees that he may bake the bread over cow excrement instead (Ezek 4.12-15). For this bread to become a contemporary symbol of healthy living requires a disregard for the entire chapter. Rhiannon Graybill points out that "to lie unmoving for more than a year, to eat food baked on excrement, to enact with one's body the destruction of the world - these are not so much attention-getting tricks as scenes of agony" (Graybill 2014, p. 139). However, just as "the language of the prophetic 'call' is also a language of coercion" (Ganzel 2014, p. 140), the language of Ezekiel Bread calls people to eat healthier bread while ignoring that the bread symbolizes starvation and deprivation, ironically, words associated with the worst elements of diet culture.

The company Food for Life has successfully marketed Ezekiel 4.9 Bread as biblically and nutritionally sound. They describe the bread as follows:

Ezekiel 4:9 products are crafted in the likeness of the Holy Scripture verse Ezekiel 4:9 to ensure unrivaled honest nutrition and pure, delicious flavors. 'Take also unto thee wheat, and barley, and beans, and lentils and millet, and spelt and put them in one vessel ... ' Ezekiel 4:9. It's this special, unique combination of 6 grains and legumes that harvests benefits beyond what we normally expect from our breads, pastas, cereals, and other foods. (Ezekiel 4:9 Sprouted Whole Grain Bread 2022)

Gary Torres, a marketing director for Food for Life, describes the group "as bakers and believers in Scripture" while noting that "not everyone agreed that a bread product named Ezekiel 4:9 was a smart idea, nor did everyone agree that a bread should have scripture on it. We believed that both were appropriate" (Miller 2008). Interestingly, Torres tries to make a bread named after a biblical verse less religious: "Ezekiel 4:9 bread has never been produced to fill a religious purpose. Rather, it's a nutritionally superior bread produced by divine inspiration" (Miller 2008). However, using the King James Version of the text would appeal to a traditional Christian audience. This is especially the case among evangelicals, who now are divided between those who will read other biblical translations and those who are King James Version only (Ward 2018).

Additionally, the health claims about the bread have been echoed in numerous secular sources. April Benshoshan calls the sprouted bread "tasty and nutritious", a low-calorie bread "loaded with micronutrients and macronutrients that'll keep you satiated and can help you lose weight or stay healthy" (Benshoshan 2019). Nikhita Mahtani declares Ezekiel Bread "a complete protein"; although it contains gluten and is not carb-free, she recommends that women eat the bread because $t$ is organic, has a low glycemic index, and is much healthier than white bread (Mahtani 2021). Kris Gunnars concurs, since sprouting increases the bread's nutritional value, which includes more fiber and no added sugars. He concludes, "If you're not gluten-sensitive and not on a carb-restricted diet, then Ezekiel bread can be a healthier choice. It's certainly a lot better than $99 \%$ of the breads on store shelves, which are usually made from refined wheat and often contain lots of sugar" (Gunnars 2018). Dr. Arefa Cassoobhoy notes that sprouted bread may not be healthier than non-sprouted bread, but she argues that "if you are going to eat bread, you will be hard-pressed to find a healthier choice than Ezekiel bread, although it may be only slightly better than others ... 
[and] is more expensive" (Cassoobhoy 2020). Only Mahtani references Ezek 4.9, quoting from the Food for Life website. No one acknowledges the unhealthy backstory of this now-healthy bread. If the use of the biblical text is only a marketing gimmick, however, then the silence makes sense.

\section{Daniel and His Transformation into a Diet and Exercise Salesman}

Similarly, the book of Daniel functions selectively as a way to market diet and exercise for evangelical Christians. Daniel 1.8-16 describes a young, exiled Israelite boy who decides not to eat unclean food, instead asking his Babylonian handler, "Please test your servants for ten days. Let us be given vegetables to eat and water to drink. You can then compare our appearance with the appearance of the young men who eat the royal rations, and deal with your servants according to what you observe" (Dan 1.12-13). Daniel and his colleagues get to keep their vegetables and water because "they appeared better and fatter than all the young men who had been eating the royal rations" (Dan 1.15; emphasis mine). In the ancient world, thinness was a sign of disease, making the use of this story as a rationale for weight loss tricky at best. As Matthias Henze notes, "The repeated remark (vv. 9, 17) that Daniel was received favorably because God wanted it so emphasizes that the good health of the youths is the result not of their peculiar vegetarian diet, but of their faithfulness to God" (Henze 2003, pp. 1233-34). It is that faithfulness that allows Daniel to survive the fiery furnace in Chapter 3 and the lions' den in Chapter 6. However, retiring pastor Rick Warren of Saddleback Church in Orange County, CA, named his diet plan The Daniel Plan because he was preaching on Daniel that day (Warren et al. 2020, p. 15). As a result, Daniel becomes a blank slate upon which Warren can write out his plan for evangelical Christians to lose weight and become healthy.

Warren's The Daniel Plan utilizes Christian biblically based rhetoric to prepare the readers to change their bodies. According to the book, now in its second edition, "The Daniel Plan is far more than a diet. It is a lifestyle program based on biblical principles and five essential components: Food, Fitness, Focus, Faith, and Friends. These last two components-faith and friends-are what I call the secret sauce that makes The Daniel Plan so effective" (Warren et al. 2020, p. 16). This requires increased self-control, and "only a Bible-based program like The Daniel Plan" can give a person the discipline necessary for success (Warren et al. 2020, p. 27). Isaiah 43.19 ("I am about to do a new thing; not it springs forth, do you not perceive it? I will make a way in the wilderness) and Jer 32.27 ("See, I am the LORD, the God of all flesh; is anything too hard for me?), texts that anticipate the end of the Babylonian exile, appear here to encourage followers new to the plan to "set some goals" (Warren et al. 2020, p. 30). Daniel functions as the perfect model: "The prophet Daniel didn't simply choose to eat healthier; he made that choice based on his faith, with a clear focus and the support of his friends. So it's no wonder that he was in better shape and health than the others in the king's court" (Warren et al. 2020, p. 32). Readers are encouraged to be

Daniel Strong. The prophet Daniel was a strong man. In body, mind, heart, and spirit, he found his power, purpose, and strength in devotion to God ... He diligently trained physically, intellectually, relationally, and spiritually with the purpose to be the best he could possibly be. With a strong body, a strong mind, a strong character, and most of all a strong faith, Daniel honored God in all he did-and you can, too. (Warren et al. 2020, pp. 39-40)

Quoting Zech 4.6b ("Not by might, nor by power, but by my spirit, says the LORD of hosts), a promise for the restoration of the Temple, Warren reminds followers of The Daniel Plan to rely on God (Warren et al. 2020, p. 51).

This reliance will be necessary in order to follow what practically is a secular, or literally non-religious, diet and exercise plan, even though the text claims to be the opposite. Warren insists, "When you focus on health, healing and weight loss happen automatically. That is exactly what happens in The Daniel Plan. The Daniel Plan was not designed as a weight loss program" (Warren et al. 2020, p. 73, emphasis mine). Disregarding the evidence that 
diets rarely work long-term (Engber 2020), Warren effectively guarantees success before describing what is a weight loss plan. The Daniel Plan perfect plate includes " $50 \%$ nonstarchy veggies; $25 \%$ healthy animal or vegetable proteins; $25 \%$ healthy starch or whole grains; side of low-glycemic fruit. Drink-water or herbal teas" (Warren et al. 2020, p. 79). The plan also recommends Ezekiel 4:9 Bread and the elimination of sugar and processed flour, because if one can control hormones such as insulin and glucose, food "cravings will vanish quickly, usually in less than forty-eight hours" (Warren et al. 2020, pp. 89, 103, 104). All readers ideally should "start with a ten-day (which you can extend to forty days) Daniel Plan Detox to jump-start the healing process, reboot your system, and discover the power of reclaiming your body and mind by letting go of the things that can harm you and adding the things that can heal you" (Warren et al. 2020, p. 124). Regarding exercise, to be Daniel Strong is to be "physically healthy ... also emotionally, relationally, and spiritually fit" (Warren et al. 2020, p. 150). One should follow the PLAY plan-“Prayerful movements throughout your day; Loosening breaks; Active games and aerobic activity; Youthful strength training" (Warren et al. 2020, p. 16). This is part of the forty-day Daniel Strong Fitness Challenge (Warren et al. 2020, pp. 176, 263, 265), which seemingly occurs simultaneously with the detox or perfect plate.

Participants should meditate on verses such as Isa 30.15, Isa 26.3, Jer 32.17, Isa 41.10, and Zeph 3.17, all quoted directly, in order to increase their trust in God's goodness and strength as they follow the plan. ${ }^{3}$ In the context of The Daniel Plan, the verses are to remind the reader that the plan is foolproof:

The Daniel Plan sets you up for success so that after forty days, you won't even have to think twice about it being your ongoing lifestyle. The key is to design your life to succeed. You will be ready for all that God has planned for you ... On The Daniel Plan you cannot fail-because you start it as a forty-day journey and then get to see changes gradually unfold over your lifetime". (Warren et al. 2020, pp. 127, 213, emphasis mine)

Therefore, even if better health has not begun to materialize after forty days, the argument is that the reader must keep going, eating their vegetables and working out. Since God is all-powerful, it is up to the person to tap into that power and change their life accordingly.

While The Daniel Plan is Warren's creation, the Daniel fast apparently is not. In a 2013 article for The Atlantic, Olga Khazan describes the fast as "eating only fruits, vegetables, and whole grains for twenty-one days," based on Daniel 1". Khazan writes, "This passage is occasionally used to encourage Christians to resist the corrupting influences of the outside world. But, several years ago, some Protestant churches began to take the 'diet' aspect of Daniel's story literally" (Khazan 2013). Rick Warren expanded the length of the fast and created his comprehensive plan as a response, with a diet "less strict than most Daniel fasts but still far more virtuous than the typical American diet", specifically, a "forty-day break from sugar, caffeine, alcohol, and any processed foods ... eventually [allowing] meat and dairy" (Khazan 2013). Khazan wonders if this trend will improve the health of evangelical Christians who may listen to their pastors while ignoring the same health advice from the federal government (Khazan 2013). A concern, however, is that connecting diet and exercise to Christianity runs the risk of creating not just a food hierarchy but a spiritual one, linking almost all health outcomes to one's relationship with God.

This link is also relatively new. Texts such as Ezekiel 4 and Daniel 1 have not historically received much attention, although Jonathan Edwards' eighteenth-century typological reading of Ezekiel as a Christ figure is noteworthy (Tooman 2009, pp. 26-27). Regarding Daniel, Michael Seufert writes, "The history of interpretation offers no unanimity of opinion, though basic positions have emerged. Interpretations of Daniel's avoidance of defilement reflects a spectrum of emphases from ritual to moral defilement," with some scholars falling in the middle (Seufert 2019, p. 645). Consequently, the texts have been able to function almost as a blank slate upon which some Christians have offered their own diet and weight loss interpretations. 


\section{So What?}

To be clear, Christian diet culture is not without its positive elements. Many plans encourage healthier eating and include recipe suggestions and lifestyle changes that can help readers to incorporate more fruits and vegetables into their diets, for example. For those who need to make those changes for health reasons, the religious encouragement could be even more valuable than the words of a nurse practitioner or dietician. The idea that God wants people to be healthier can be a positive one.

Other theological implications of Christian diet culture, however, have been and should continue to be problematized. Linking nutrition and diet to any type of divine sanction appears both presumptuous and anxiety-producing. In her analysis of The Weigh Down Diet (now Workshop), Lauren F. Winner notes that Christian diet programs have become big business, with people spending at least USD 1.5 billion annually (Winner 2000, p. 52). Like the food and weight loss programs analyzed in this article, The Weigh Down Diet's "approach to Scripture relies heavily on freestyle prooftexting" (Winner 2000, p. 55). For example, its creator Gwen Shamblin uses Matt 6.25 ("Do not worry about your life, what you will eat or what you will drink") not only as Jesus "teaching about anxiety and trust in God; he also means that folks should not worry about getting enough fiber" (Winner 2000, p. 55). Winner fears that "although evangelicals are typically outspoken in their analysis of worldliness, weight is one area where we seem to have embraced a worldly aesthetic uncritically" (Winner 2000, p. 57). Being overweight can be a sign that one's Christian journey is off track (Winner 2000, pp. 57-58). While biblical interpretation should be contextually specific, using texts that have nothing to do with diet or exercise in order to create a pro-thinness ideology distorts those texts. Ezekiel and Daniel did not enter the Christian canon for the purposes of weight loss. They serve that contemporary purpose today; however, they appear as a potentially problematic recent example of reception history. Prophets regularly call for repentance, a turn away from behavior that displeases God and a turn towards love of God and people. Linking that call to a turn away from sweet or salty snacks distorts that message for profit, even if the goal is well-intentioned. While some may need to lose weight to lower blood pressure or manage type 2 diabetes, when others who are at a healthy weight choose to diet to become even thinner or to lose twenty unnecessary pounds or reform a "disgusting (size 16) body" (Winner 2000, pp. 57-58), the Bible becomes a source not for inspiration but for stress. The prophets condemned bad behavior, but they did not engage in fat or food shaming; using them even indirectly for that purpose is a misuse of the texts. While Winner's article is more than two decades old, her argument remains both rare and timely. It is rare in the sense that few scholars after her have taken a critical view of Christian diet culture's use of Scripture, and it is timely because Christian diet culture remains both popular and profitable.

Moving from theological to cultural implications, Christian diet plans, with their rhetoric of health, are gendered and raced, skewing heavily towards White women. The most popular plans are written by White men or women (Rick Warren and Gwen Shamblin Lara, to name two), and those needing the help are almost always presumed to be women (Rubin 2005, p. 1). The New Life Promise Program is tailored almost exclusively to White women, with the occasional PGM (people of the global majority) woman appearing in the thirty-nine-minute infomercial, along with the claim that "renewed sexual intimacy is a wonderful side effect of giving your body the foods it truly needs, but it is often not talked about" (Isabel Price Shares God's Word 2022). Even Kimberly Taylor's Take Back Your Temple plan, designed by an African American woman, "is a Christian weight loss plan for women, founded on prayers for losing weight that ask God for restoration of our bodies as His temple" (Take Back Your Temple n.d.). These prayers include the Supernatural Weight Loss Prayer, Body Restoration Prayer, and Prayer for Weight Loss: Combat Discouraging Thoughts. The plan's primary focus is on "emotional eating" (Become the Person God Created You to Be n.d.), which gets linked primarily to women; images from articles from Harvard Health Publishing (a lipstick-wearing White woman with manicured nails, biting into a chocolate bar); a WebMD slideshow in which the first two slides that show emotional 
eating are women with pizza, soda, potato chips, cookies and candy; and the Cleveland Clinic's image of a woman eating Chinese food directly from the carton clearly suggest as much (Godman 2017; Casarella 2020; 5 Strategies to Help You Stop Emotional Eating 2020). The association of certain "bad" eating habits with women, combined with an emphasis on Whiteness and/or thinness, can make Christian diet culture a less-than-ideal space for women who do not fit this model. In response to the 2021 HBO documentary The Way Down: God, Greed, and the Cult of Gwen Shamblin, The Weigh Down Workshop stated, "We do not body shame or bully anyone, as we know that God created us all uniquely with different sizes, shapes and weights ... We love people of all sizes and our goal is to help all to find God in a most loving manner" (The Truth About the Way Down HBO Documentary 2021). However, when the program's success stories include links to women's (and men's) weight loss, with thirteen of the first eighteen stories about White women (Success Stories 2021), one can realistically wonder where someone who does not lose the weight will fit. Additionally, with questions being raised about the role of race in BMI calculators (Alexis 2021), one can also wonder whether such plans, even the rare one marketed by a PGM woman, are a good idea.

\section{Conclusions}

Is there a potentially more biblically sound and less problematic way for Christians to talk about food without diet culture rhetoric? Catholic moral theologian Beth K. Haile and Mennonite philosopher Matthew C. Halteman answer yes. Haile analyzes whether Christians can ethically eat meat and uses virtue ethics to say that they can (Haile 2013, p. 84). She cites the work of Hugh Fearnley-Whittingstall as an example of "individuals who make the conscious choice to consume meat, and yet still seem to lead lives oriented toward the good", including through advocacy for meat produced humanely (Haile 2013, p. 87). Haile argues, however, that such advocacy cannot occur strictly for the purposes of selling more expensive meat or for buyers to look more righteous. Meat can be eaten ethically in moderation, especially if the meat is not wasted (Haile 2013, pp. 90-93). Haile concludes, "Raising animals and consuming meat responsibly, healthfully, moderately, and thriftily are all ways of caring for God's creation" (Haile 2013, p. 95). Additionally, vegetarians can also have the same virtuous goals of caring for the earth (Haile 2013, pp. 96-97). Halteman studies "the standard American diet-a diet composed largely of animal products sourced mainly from industrial farms", which most Christians eat, and argues that "the church should actively encourage Christians to discern and adopt more redemptive eating habits, and Christians who are able should take action toward this end" (Haile 2013, pp. 383-84). Using Gal 5.22's list of the fruits of the Spirit as a guide, Halteman talks about food systems in general and not diets in particular and calls for a return to the broader Christian tradition of caring for the earth (Haile 2013, pp. 386, 388, 390). He notes that the Hebrew Bible includes vegetarianism and omnivorism but that the standard American diet goes against biblical calls to protect God's creation (Halteman 2013, pp. 391, 394). Additionally, scholar David Grumett has taken his interest in the history of Christian approaches to food and applied it to contemporary ethical questions of farming practices in the United Kingdom.

The mercy that these scholars offer is the lack of discussion of how a person's diet affected their physical body. Instead, food became not a tool for weight loss or individual health but the health of the planet, without a prophetic prooftext in sight. While this may not be an evangelical approach, it can become one. The new but expanding field of ecological biblical criticism offers a method for reading texts about bodies and creation in more holistic ways, and evangelicals are beginning to utilize it (Leese 2019). Hosea 4.1-3 argues that human bad behavior harms all of the animals, and they too are God's creation-see Jonah 4.9-11, in which God argues that the plants, animals, and Ninevites are all important. If Christian diet culture limits the Bible and food to how they can personally benefit the individual, a broader concern with food justice places the focus upon the planet 
as a whole. That may not be the most common use of prophetic reception history today, but it may be the more life-affirming one.

Funding: This research received no external funding

Institutional Review Board Statement: Not applicable.

Informed Consent Statement: Not applicable.

Data Availability Statement: Not applicable.

Conflicts of Interest: The author declares no conflict of interest.

\section{Notes}

1 Jordan S. Rubin's 2005 book The Maker's Diet describes a Garden of Eden plan, advocating that people only eat foods based primarily on Genesis, Leviticus, and Deuteronomy. Butter and honey are acceptable, because of the quotation of Isa 7.15- "The Bible implies a strong influence of butter and honey on brain function. 'Curds [butter] and honey He shall eat, that He may know how to refuse the evil and choose the good" (Rubin 2005, p. 151). Ezekiel 47.12 is "a fascinating biblical portrait of divine health when he spoke of healing leaves and refreshing fruit" (Rubin 2005, p. 178). Rubin credits the diet with saving his life and helping him regain some of the weight he lost due to Crohn's disease (Miller 2006, p. 65). In a review for Christianity Today, Eric Miller notes that the "book reads like an informercial, with sentimental testimonials, grand pronouncements, and ardent sales pitches. It's hard, in this light, not to see Rubin's remarkably free use of the term 'Maker's diet' as a profanely commercial appropriation of that which ought to remain holy" (Miller 2006, p. 66). An example of a Success With God plan is the late Gwen Shamblin Lara's Weigh Down Workshop: “By studying God's perfect design and naturally thin eaters, Gwen was permanently set free from overweight and diets. Soon, people turned to her for help to lose weight" (About Gwen 2021). The plan's website states, "Weigh Down is a revolutionary faith-based approach to overcoming obesity, overweight, and other eating disorders. The concept is simple: eat when you are hungry and stop when you are full ... Therefore, what is the missing key to rising above the magnetic pull of the refrigerator? God" (Weigh Down: The Solution to Permanent Weight Loss 2021).

2 See Amy-Jill Levine's essay in the Jewish New Testament, "Bearing False Witness: Common Errors Made About Early Judaism", which warns against Christians trying to remove Jesus from his Jewish context.

3 Isaiah 30.15 ("For thus said the Lord God, the Holy One of Israel: In returning and rest you shall be saved; in quietness and in trust shall be your strength) is part of a prophetic critique of the people's disobedience. Otherwise, the remaining texts are used effectively. Jeremiah 32.17 ("Ah Lord God! It is you who made the heavens and the earth by your great power and by your outstretched arm! Nothing is too hard for you) is part of the book of consolation, and Isa 26.3 ("Those of steadfast mind you keep in peace-in peace because they trust in you) appears within a song of praise. Jeremiah 29.11 ("For surely I know the plans I have for you, says the Lord, plans for your welfare and not your harm, to give you a future with hope), Isa 41.10 ("Do not fear, for I am with you, do not be afraid, for I am your God; I will strengthen you, I will help you, I will uphold you with my victorious right hand), and Zeph 3.17 ("The Lord your God is in your midst, a warrior who gives victory; he will rejoice over you with gladness, he will renew you in his love) are all exilic texts designed to encourage and sustain the people in a difficult time.

\section{References}

5 Strategies to Help You Stop Emotional Eating. 2020. Cleveland Clinic, May 15. Available online: www.health.clevelandclinic.org/5strategies-to-help-you-stop-emotional-eating/ (accessed on 20 January 2022).

About Gwen. 2021. Available online: www.gwenshamblinlara.com/about (accessed on 30 September 2021).

Alexis, Amber Charles. 2021. Is BMI a Fair Health Metric for Black Women? Healthline, December 1. Available online: www.healthline. $\mathrm{com} /$ nutrition/bmi-for-black-women (accessed on 20 January 2022).

Become the Person God Created You to Be. n.d. Available online: www.takebackyourtemple.com/about-us/ (accessed on 26 August 2021).

Benshoshan, April. 2019. What Is Ezekiel Bread and Why Are People Obsessed with It? Eat This, Not That! October 29. Available online: www.eatthis.com/ezekiel-bread (accessed on 26 August 2021).

Casarella, Jennifer. 2020. How to Stop Emotional Eating from Stress. WebMD, May 11. Available online: www.webmd.com/balance/ stress-management/ss/slideshow-stop-emotional-eating (accessed on 20 January 2022).

Cassoobhoy, Arefa. 2020. Ezekiel Bread: Is It Good for You? WebMD, September 21. Available online: www.webmd.com/diet/ezekielbread-is-it-good-for-you\#1www.davidgrumett.com (accessed on 26 August 2021).

Chastain, Ragan. 2022. Recognizing and Resisting Diet Culture. National Eating Disorders Association. Available online: https: / / www.nationaleatingdisorders.org/blog/recognizing-and-resisting-diet-culture (accessed on 6 January 2022).

Dry January. 2022. Available online: https://alcoholchange.org/uk/get-involved/campaigns/dry-january/why-do-dry-january-1/ why-do-dry-january (accessed on 6 January 2022).

Engber, Daniel. 2020. Unexpected Clues Emerge about Why Diets Fail. Scientific American, January 13. Available online: https: // www.scientificamerican.com/article/unexpected-clues-emerge-about-why-diets-fail/ (accessed on 18 January 2022). 
Ezekiel 4:9 Sprouted Whole Grain Bread. 2022. Available online: www.foodforlife.com/about_us/ezekiel-49 (accessed on 26 August 2021).

Faries, Mark D., Megan McClendon, and Eric J. Jones. 2020. Destroying God's Temple? Physical Activity, Poor Diet, Obesity, and Other 'Sin' Behaviors. Journal of Religion \& Health 59: 522-34. [CrossRef]

Fields, Leslie Leyland. 2013. The Fitness-Driven Church. Christianity Today, June 21, 39-43.

Ganzel, Tova. 2014. Ezekiel. In The Jewish Study Bible, 2nd ed. Edited by Adele Berlin and Marc Zvi Brettler. New York: Oxford University Press, pp. 1033-123.

Godman, Heidi. 2017. Struggling with emotional eating? Harvard Health Letter, August 15. Available online: www.health.harvard.edu/ diet-and-weight-loss-struggling-with-emotional-eating (accessed on 20 January 2022).

Graybill, Rhiannon. 2014. Voluptuous, Tortured, and Unmanned: Ezekiel with Daniel Paul Schreber. In The Bible and Posthumanism. Edited by Jennifer L. Koosed. Atlanta: Society of Biblical Literature, pp. 137-55.

Griffith, R. Marie. 1999. Fasting, Dieting, and the Body in American Christianity. In Perspectives on American Religion and Culture. Edited by Peter W. Williams. Malden: Blackwell, pp. 216-27.

Gunnars, Kris. 2018. Why Ezekiel Bread Is the Healthiest Bread You Can Eat. Healthline, May 22. Available online: www.healthline. com/nutrition/ezekiel-bread (accessed on 26 August 2021).

Haile, Beth K. 2013. Virtuous Meat Consumption: A Virtue Ethics Defense of an Omnivorous Way of Life. Logos 16: 83-100. [CrossRef]

Halteman, Matthew C. 2013. Knowing the Standard American Diet by Its Fruits: Is Unrestrained Omnivorism Spiritually Beneficial? Interpretation 67: 383-95. [CrossRef]

Henze, Matthias. 2003. Daniel. In The New Interpreter's Study Bible. Edited by Walter J. Harrelson. Nashville: Abingdon, pp. 1231-252.

Isabel Price Shares God's Word. 2022. Available online: www.isabeldprice.com/1/7531?food=Turkey\&gclid=EAlalQobChMljvLEuJu5 9QIVShZMCh1s-Q5NEAMYASAAEgLZnvD_BwE (accessed on 26 August 2021).

Khazan, Olga. 2013. The Diet from God. The Atlantic, November 26. Available online: www.theatlantic.com/health/archive/2013/11/ the-diet-from-god/281816/ (accessed on 26 August 2021).

Kwan, Samantha, and Christine Sheikh. 2011. Divine Dieting: A Cultural Analysis of Christian Weight Loss Programs. In Food and Faith in Christian Culture. Edited by Ken Albala and Trudy Eden. New York: Columbia University Press, pp. $205-19$.

Leese, J. J. Johnson. 2019. Ecofaith: Reading Scripture in an Era of Ecological Crisis. Religions 10: 154. [CrossRef]

Mahtani, Nikhita. 2021. Wait, Is Ezekiel Bread Actually Good For You? Women's Health, May 14. Available online: www. womenshealthmag.com/food/a36383025/ezekiel-bread-nutrition (accessed on 26 August 2021).

Miller, Eric. 2006. Choking on Modernity: The Maker's Diet Is Part of the Problem. Christianity Today, May 1, pp. 65-66.

Miller, Jessica. 2008. Discussing the Divine Recipe for Exekiel 4:9 with Food for Life Breadhead Gary Torres. Jewcy, June 25. Available online: https://jewcy.com/arts-and-culture/discussing_divine_recipe_ezekiel_4_9_food_life_breadhead_gary_torres (accessed on 13 January 2022).

Nittle, Nadra. 2019. Why Bible-inspired diets and fitness plans are catching on. Vox, February 1. Available online: www.vox.com/thegoods-2019/2/1/18207293/chris-pratt-daniel-fast-daniel-plan-bible-diets (accessed on 26 August 2021).

Rubin, Jordan S. 2005. The Maker's Diet. Lake Mary: Siloam.

Seufert, Matthew. 2019. Refusing the king's portion: A reexamination of Daniel's dietary reaction in Daniel 1. JSOT 43: 644-60. [CrossRef]

Success Stories. 2021. Available online: www.weighdown.com/weigh-down-success-stories/womens-weight-loss/page/1/2/3/ (accessed on 20 January 2022).

Take Back Your Temple. n.d. Available online: www.takebackyourtemple.com (accessed on 26 August 2021).

The Truth About the Way Down HBO Documentary. 2021. Available online: www.remnantfellowshiop.org/official-response-fromgwen-shamblin-church-to-hbo-documentary (accessed on 30 September 2021).

Tooman, William. 2009. Edwards' Ezekiel: The Interpretation of Ezekiel in the Blank Bible and Notes on Scripture. Journal of Theological Interpretation 3: 17-38. [CrossRef]

Tull, Patricia. 1999. Rhetorical Criticism. In To Each Its Own Meaning: An Introduction to Biblical Criticisms and Their Applications. Edited by Steven L. McKenzie and Stephen R. Haynes. Louisville: Westminster John Knox, pp. 156-80.

Ward, Mark. 2018. 3 Ways to Graciously Engage KJV-Only Believers. The Gospel Coalition, July 26. Available online: www.https: //www.thegospelcoalition.org/article/3-ways-graciously-engage-kjv-believers/ (accessed on 15 February 2022).

Warren, Rick, Daniel Amen, and Mark Hyman. 2020. The Daniel Plan: 40 Days to a Healthier Life. Grand Rapids: Zondervan.

Weigh Down: The Solution to Permanent Weight Loss. 2021. Available online: www.weighdown.com/about (accessed on 30 September 2021).

What We Do. 2022. Available online: https:/ / veganuary.com/en-us/about/about-us (accessed on 6 January 2022).

Winner, Lauren F. 2000. The Weigh and the Truth. Christianity Today, September 4, pp. 51-58. 